University of Nebraska - Lincoln

DigitalCommons@University of Nebraska - Lincoln

Papers in the Earth and Atmospheric Sciences Earth and Atmospheric Sciences, Department

January 2008

\title{
Deciphering climatic history from lake sediments
}

Sherilyn C. Fritz

University of Nebraska-Lincoln, sfritz2@unl.edu

Follow this and additional works at: https://digitalcommons.unl.edu/geosciencefacpub

Part of the Earth Sciences Commons

Fritz, Sherilyn C., "Deciphering climatic history from lake sediments" (2008). Papers in the Earth and Atmospheric Sciences. 16.

https://digitalcommons.unl.edu/geosciencefacpub/16

This Article is brought to you for free and open access by the Earth and Atmospheric Sciences, Department of at DigitalCommons@University of Nebraska - Lincoln. It has been accepted for inclusion in Papers in the Earth and Atmospheric Sciences by an authorized administrator of DigitalCommons@University of Nebraska - Lincoln. 
Published in Journal of Paleolimnology 39 (2008), pp. 5-16; doi 10.1007/s10933-007-9134-x

Copyright (C) 2007 Springer Science+Business Media B.V. Used by permission.

http://springerlink.metapress.com/content/100294/

Submitted January 8, 2007; accepted July 1, 2007; published online September 25, 2007

This paper is based on a plenary talk at the 10th International Paleolimnology Conference in Duluth, Minnesota in July 2006.

\title{
Deciphering climatic history from lake sediments
}

\author{
Sherilyn C. Fritz
}

Department of Geosciences and School of Biological Sciences, University of Nebraska - Lincoln, Lincoln, NE 68588-0340, USA

email sfritz2@unl.edu

\begin{abstract}
Reconstructing climate from lake sediments can be challenging, because the response of lakes and various components of lake systems are mediated by non-climatic factors, such as geomorphic and hydrologic stetting. As a result, the magnitude of lake response to climatic forcing may be non-linear. In addition, changes in the lake system associated with the aging process or non-climatic influences may alter the response to a given climate perturbation. These non-linear and nonstationary characteristics can produce spatial heterogeneity in the pattern and timing of inferred change. One approach for generating regionally robust climatic interpretations from lakes is to increase coordinated efforts to generate and synthesize large data sets, so that localized influences can be more clearly distinguished from broad-scale regional patterns. This approach will be most successful for evaluating climate variation at multi-decadal or longer temporal scales; the climatic interpretation of higher frequency limnological variation can be more complicated, because of dating uncertainties and differential response times of individual proxies and systems.
\end{abstract}

Keywords: paleolimnology, paleoclimate, paleohydrology, lakes, lake-level change, salinity

\section{Introduction}

Lake deposits have been used increasingly in recent years to infer past fluctuations in climate, and many studies, spanning diverse locations and time scales, demonstrate the great value of lakes as paleoclimatic archives (Cohen 2003). Along with the growth in lacustrine paleoclimatic studies has come a growing recognition of the complexities in inferring climate from these records. The response of a lake to climate is mediated by the hydrologic and geomorphic setting of the basin, and consequently translating from the localized responses of individual lakes to the landscape or regional scale can be challenging. Relating temporal lacustrine variability to temporally variable forcing factors is also difficult in many circumstances. In this paper, I review some of the progress that we have made over the last decade in interpreting climatic history from paleolimnological records. I also highlight some of the issues that I think require continued attention and suggest a few approaches that can be used to move forward. I focus primarily on reconstruction of effective moisture (precipitation minus evaporation, $\mathrm{P}-\mathrm{E}$ ) from lake sediments, because this is the subject that I know best, but many of the comments that I make are applicable to inferences of other climatic parameters. 
This paper is not intended to be a comprehensive review of the literature but rather a personal perspective on the questions that interest me and that I continue to struggle with.

\section{Scaling the response of proxies and lakes to climate}

Individual proxies and lakes can respond to climate in a non-linear manner, and it is difficult to infer the magnitude, or in some cases even the direction, of change in climate from paleolimnological records. An early reconstruction of lake-level change in central Minnesota (Digerfeldt et al. 1993) demonstrated that lakes within a small geographic area showed pronounced differences in the magnitude of lake-level lowering in response to drought. A transect of cores from deep to shallow water was used to measure lake-level change in each of four lakes and documented that mid-Holocene lake-level lowering ranged from $3 \mathrm{~m}$ to $7 \mathrm{~m}$ (Figure 1). This variability among lake basins is related to groundwater influences on individual lakes-lakes close to a river, and hence base level, varied less than those distant from the river (Almendinger 1993).

Biotic records often are used to reconstruct lake level using shifts in the abundance of planktic species, characteristic of deeper open-water areas of the lake, relative to near-shore shallow-water forms (benthic). As lake level is lowered, shallow-water areas of a lake that are exposed to sunlight commonly

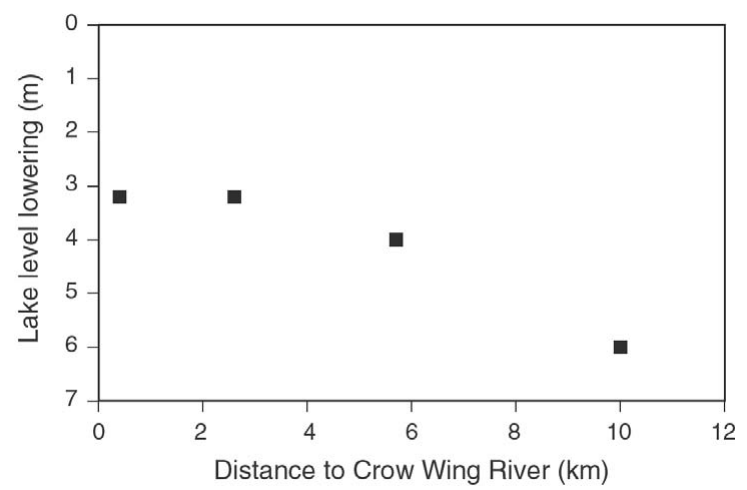

Figure 1 Magnitude of lake-level lowering (meters) relative to distance from the nearest major river for four lakes on a sand plain in west-central Minnesota, USA. Redrawn from Digerfeldt et al. (1993) extend closer to the lake's center. As a result, the input of benthic organisms to a mid-lake coring location increases. In lakes with a complex morphometry, however, the relationship between lake-level change and change in the proportion of benthic taxa may be non-linear, and in some cases benthic diatoms may actually decrease in abundance as lake level declines (Stone and Fritz 2004). This situation was evaluated and modeled at Foy Lake in the Rocky Mountains, USA, in order to characterize the relationship between lake-level change and massive changes in the abundance of planktic diatoms relative to benthic diatoms during the last 2,000 years. This lake has two basins that are connected via a broad shallow shelf during times of high lake level (Figure 2a, b). When the two basins are joined, this platform is a source of benthic diatoms to the lake's deep hole. But as lake level drops, the two basins become isolated, and the larger basin loses its connection with the large platform colonized by benthic diatoms. As a result, the proportion of benthic diatoms actually decreases, at least initially (Figure 2c). This semi-quantitative model of diatom response to lake-level variation, in combination with stable isotope data from authigenic carbonates (Stevens et al. 2006), suggests that lake level in the last $\sim 1,200$ years has fluctuated up and down within a few meters of the elevation where the two basins are joined. It is likely that spikes in benthic diatoms at $\sim \mathrm{AD} 1350$ and 1650 (Figure 2d) represent a lake-level rise, when the shallow shelf joining the two lakes was flooded, after an interval when the two basins were isolated. The uppermost spike dates from the Dust Bowl period in the 1930s, when lake level fell, and the two basins were isolated. Thus, in this lake system, the relationship between climate and the lake proxies is not always linear and also is non-stationary, in that it actually changes in sign.

In closed-basin lakes, measures of ionic concentration (e.g. salinity, conductivity, $\delta^{18} \mathrm{O}$ ) are commonly used as proxies for $\mathrm{P}-\mathrm{E}$, because precipitation and evaporation dilute and concentrate dissolved salts (Eugster and Hardie 1978). But salinity can be related to P-E in some fairly complex ways, particularly for lakes where groundwater is a significant component of the water budget. For example, a spring-fed pool in the Konya Basin of Turkey and an adjacent closed basin, with little groundwater input, showed divergent responses to the same cli- 


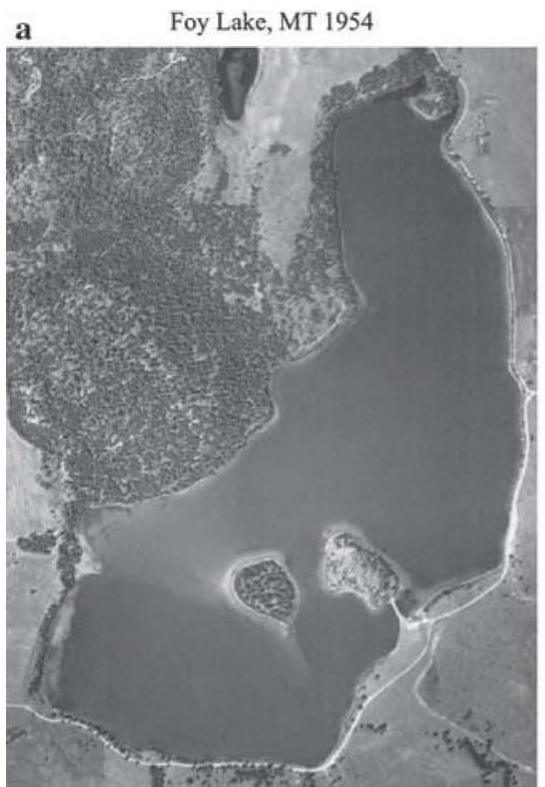

c

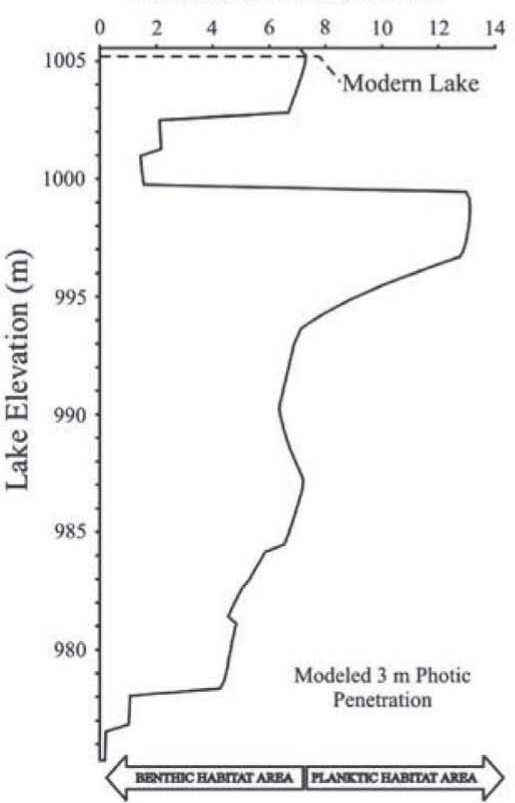

b

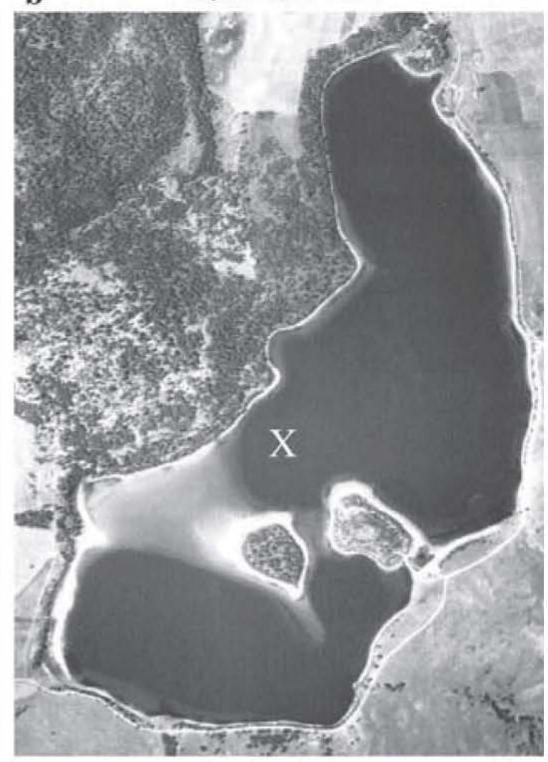

d Percent Abundance of Benthic Diatoms

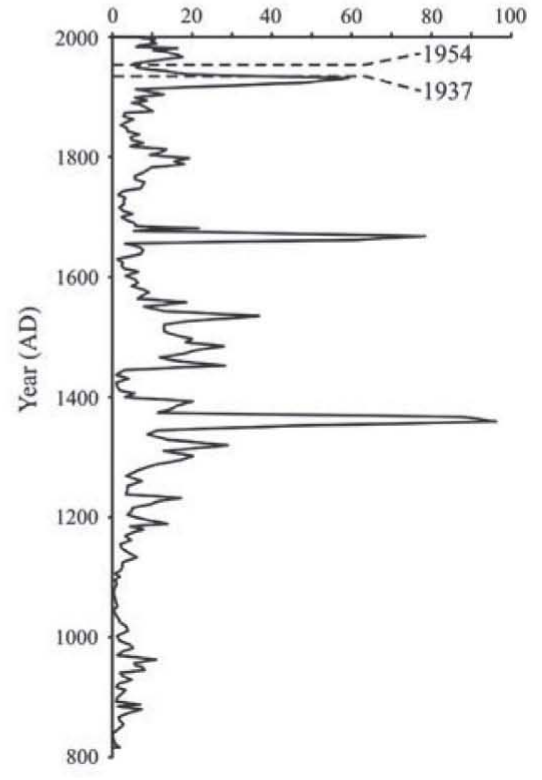

Figure 2 (a) Aerial photo of Foy Lake, MT, USA, during a wet year when the two sub-basins are joined, and (b) in a dry year when the basins are nearly isolated. The coring location is marked with an X. (c) Changes in the proportion of planktic (deep water) to benthic (shallow water) diatoms at the deep-water coring site of Foy Lake as lake elevation changes; higher abundance of planktic species plots to the right. (d) Abundance of benthic diatoms in a core from Foy Lake during the last $\sim 1,200$ years; the spikes in benthic diatoms occur when the lake elevation is between $\sim 1,000$ and $1,002.5 \mathrm{~m}$. Modified from figures in Stevens et al. (2006) mate change (Reed et al. 1999). In a multi-proxy reconstruction from a lake in the USA Great Plains, ostracode $\mathrm{Mg} / \mathrm{Ca}$ ratios increased during the midHolocene, suggesting higher temperatures and evaporation associated with major drought, whereas oxygen isotopic values of ostracode calcite became more depleted (Smith et al. 2002). A companion study of the groundwater setting of this lake (Donovan et al. 2002) suggested that, during major drought, ground- water influx to the lake may increase, because shallow basins higher in the groundwater flow system dry up. This increases inflow of groundwater, which is isotopically depleted. In a study of Ethiopian lakes, paleoshorelines above the modern lake document an interval of higher precipitation than today, but a reconstruction of salinity based on diatoms suggests that lake-water salinity increased at the same time (Telford et al. 1999). In this case it is likely that the 
counter-intuitive pattern of elevated salinity during a wet period resulted because higher precipitation enhanced groundwater recharge and increased inputs of groundwater, which in this case was saline.

In high-latitude regions, permafrost may limit the influence of groundwater, but relating the magnitude of salinity change directly to climate still can be difficult. A diatom-inferred conductivity record from a lake in West Greenland (McGowan et al. 2003) shows a series of inferred fluctuations after 5,000 cal year BP from $<1,000$ to $\sim 4,000 \mu$ s (Figure 3$)$. One is tempted to interpret this as a sequence of two major declines in lake-level, with high-frequency variation in the intervening periods. A geo- morphic record of adjacent paleoshorelines and associated radar and seismic data were used to construct a lake-level curve (Figure 3), which clarifies the interpretation of the conductivity record (Aebly and Fritz 2007). The large drop in lake level of more than four meters after $\sim 3,500$ cal year BP is manifested as a small increase in conductivity; the subsequent lakelevel rise, of nearly the amount as the prior decline, is not linearly scaled with the associated drop. Both the geomorphic and proxy record show that the modern lake is at the lowest level of the last $\sim 5,000$ years, and the combination of these data clearly illustrate that conductivity change and lake-level change are not related in a simple linear function.
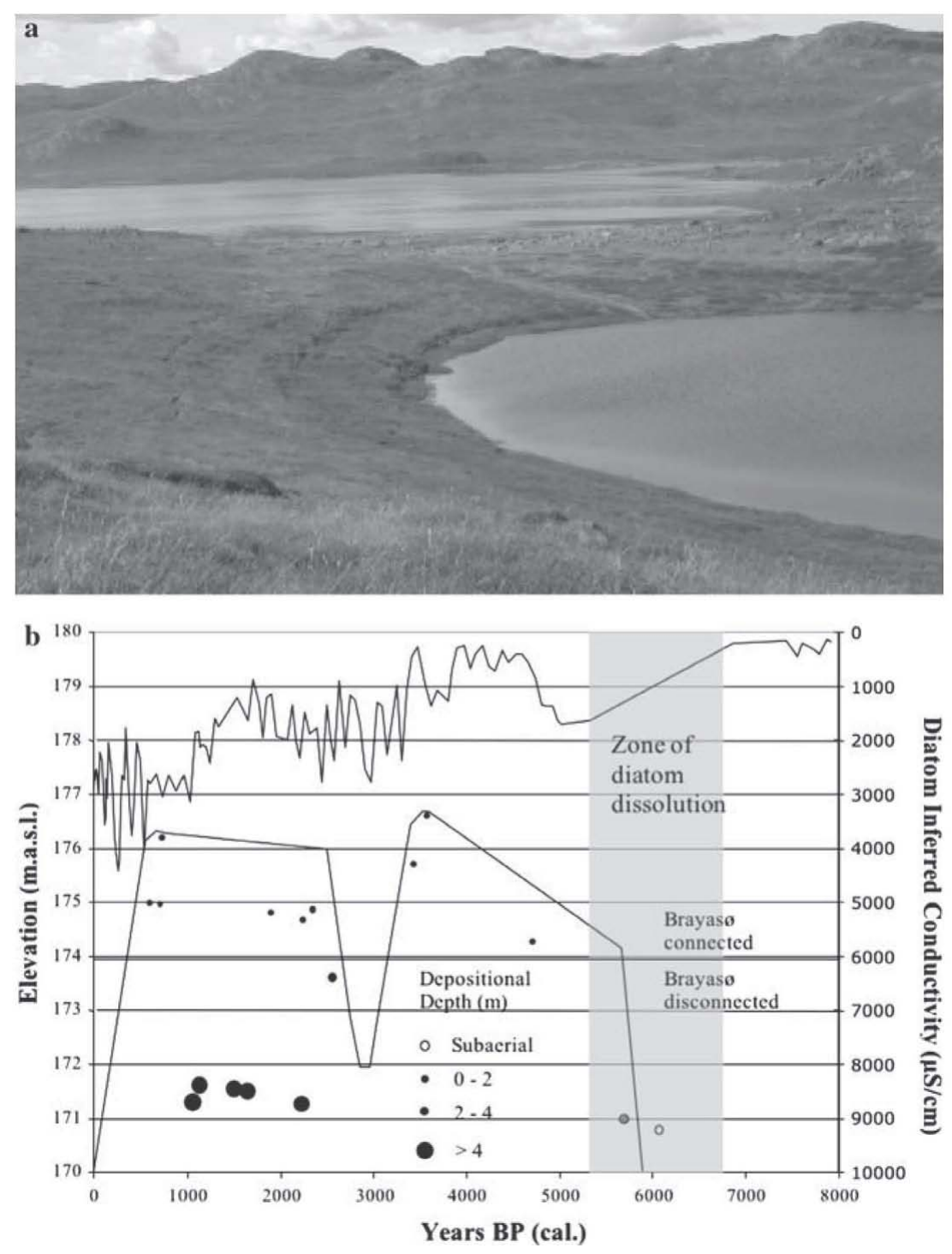

Figure 3 (a) Photograph of paleoshorelines in the Kangerlussuaq region of West Greenland. (b) A lake-level reconstruction for the last 6,000 years generated from measuring the elevation of the paleoshorelines and associated radiocarbon and grainsize measurements within the shorelines. The size of the filled circle represents the inferred depositional depth of the radiocarbon-dated sample, based on a comparison of grain-size measurements in the shoreline sample with those from the modern depositional system. The lakelevel reconstruction is compared with a reconstruction of conductivity inferred from diatoms in a sediment core in an adjoining lake. Modified from Aebly and Fritz (2007) and McGowan et al. (2003) 


\section{Spatial variability}

Another challenge in generating climate reconstructions from lakes involves spatial variability and the issue of differentiating localized versus regionalized patterns of change. The differences in the response of individual lake basins to climate, as just discussed, can produce stratigraphic records that differ in the timing, magnitude, and sometimes even direction of limnological change, even within a restricted geographic region. A classic example comes from our work in the Great Plains region of the USA. A highresolution reconstruction of salinity change, based on the Moon Lake diatom record, showed a major shift to fresher conditions about AD 1200, which we interpreted as evidence of a directional shift to higher precipitation during the Little Ice Age period (Laird et al. 1996). However, subsequent studies at other regional lakes showed that, at this time, the direction of diatom-inferred salinity change is opposite in a lake only $200 \mathrm{~km}$ away, and a lake several hundred kilometers further west, with an ostracode-inferred $\mathrm{Mg}$ / Ca reconstruction, does not show a directional shift at all (Fritz et al. 2000). Differences in the spatial pattern of lake response may reflect either a spatial gradient in climate from east to west or differential groundwater influence, such that one lake became fresher and the other saltier. In order to differentiate between individual lake response and a regional climate signal, we need to more rigorously evaluate the situations and scales at which lakes can be used as climate recorders.

In a very small number of regions, the number of high-resolution records is becoming sufficient to evaluate whether there is clear spatial structure in paleolimnological trajectories. For example, recent research in equatorial Africa shows spatially variable patterns of lake-level change that likely reflect climate gradients (Russell and Johnson 2007). Lakes in central Africa show proxy evidence suggesting major drought during the Little Ice Age interval, whereas lakes to the east suggest wet conditions (Verschuren et al. 2000). This spatial structure (Figure 4) can be explained by differential sensitivity of the two regions to ENSO and migration of the Intertropical Convergence Zone (ITCZ) associated with high-latitude cooling. Although the directional changes in climate can be inferred from this assemblage of sites for the transition from the Medieval Period into the

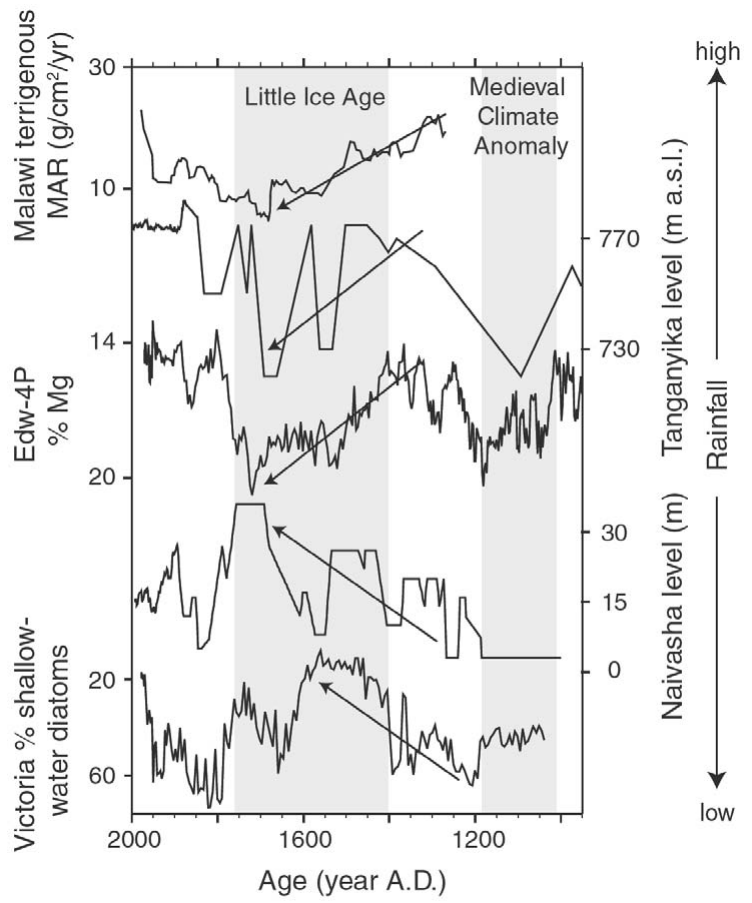

Figure 4 A comparison of lake-level proxies from two lakes in east Africa (Naivasha, Victoria) and three lakes in central Africa (Malawi, Tanganyika, Edwards) showing the out-of-phase behavior of the two regions during the Little Ice Age interval. Direction of lake-level change is shown by the arrows. Modified from Russell and Johnson (2007)

Little Ice Age, the differential patterns of higher frequency (multi-decadal) variation are more difficult to interpret in terms of climatic forcing.

In other cases, localized factors, particularly hydrologic setting, may be a primary cause of different patterns of paleolimnological change. Contemporary regional limnological data sets show large spatial heterogeneity in climatically sensitive water-chemistry variables, such as salinity. This variability is a product of spatial heterogeneity in the bedrock or in the importance of various components of each lake's water budget. For example, within a $100 \mathrm{~km}^{2}$ area of western Nebraska, USA, measured surface-water salinity in lakes spans nearly three orders of magnitude $\left(0.3-120 \mathrm{~g} \mathrm{l}^{-1}\right)$, whereas the groundwater is less variable (0.1-1.7 $\mathrm{g} \mathrm{l}^{-1}$ ) (Zlotnik et al. 2007). The fresher lakes are those at low elevation where a large portion of the inflow is fresh groundwater, whereas many of the higher elevation lakes have limited or no inputs of groundwater, and they are concentrated by 

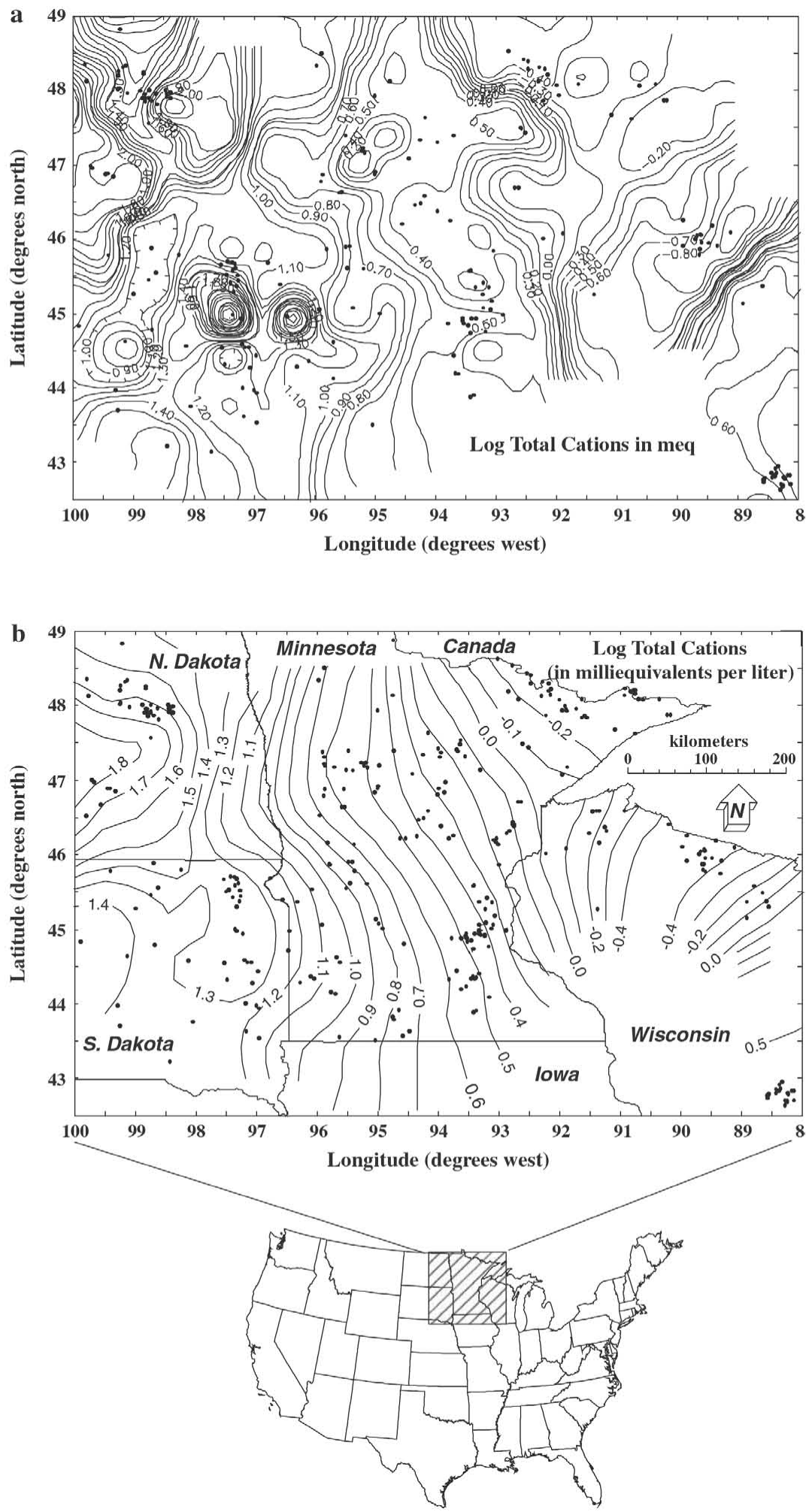

Figure 5 Cation concentration in lakes in the north-central USA. Values in the lower figure (b) have been smoothed before contouring, whereas those in the upper figure (a) have not. The unsmoothed data emphasize localized variability (upper figure), whereas the smoothing (lower figure) emphasizes the overall regional pattern of increased cation concentration as effective moisture decreases from east to west. Lower figure from Dean (1999), reprinted with permission of Springer Science and Business Media; upper figure courtesy of Walt Dean 

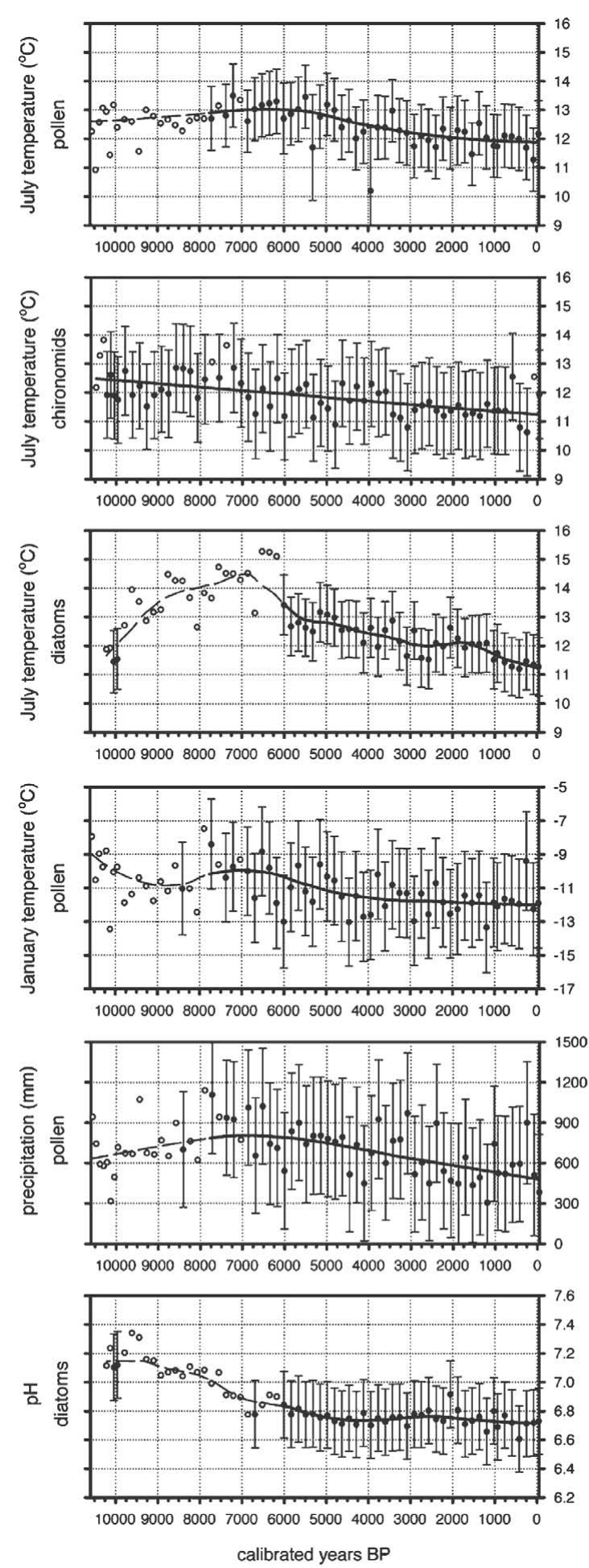

evaporation in an arid climate. This localized heterogeneity is embedded in a larger pattern driven by climate; overall the lakes are fresh and dilute in
Figure 6 Multi-proxy reconstructions of temperature for a lake in Sweden. Note that the pattern in the July temperature reconstruction based on diatoms is very different between 10,000 and 7,000 cal year BP than the reconstructions based on pollen and chironomids. This interval corresponds with an interval when the diatom data suggest a decrease in lake $\mathrm{pH}$ associated with soil development. From Bigler et al. (2002), reproduced by permission of Sage Publications Ltd

the eastern part of Nebraska, where precipitation is higher ( 700 $\mathrm{mm}_{\text {year }}{ }^{-1}$ ), whereas the only saline lakes occur in the more arid western part of the state $\left(<450 \mathrm{~mm}\right.$ year $\left.^{-1}\right)$.

The interaction of both climatic gradients $(\mathrm{P}-\mathrm{E})$ and localized factors in influencing lake salinity has been illustrated by Walt Dean and his colleagues, who sampled water chemistry in hundreds of lakes in the north-central USA that span a strong $\mathrm{P}-\mathrm{E}$ gradient, from high in the east to low in the west (Gorham et al. 1983). When viewed across a large geographic area, ionic concentration increases as P-E decreases. This pattern is evident in Figure 5b, where the water chemistry data have been smoothed and contoured. If the data are not smoothed (Fig 5a), the water-chemistry variability attributable to localized effects is apparent. With paleolimnological data, there are relatively few compilations of multiple sites within a region or even at the multi-regional scale; two examples of multi-regional comparisons are for lake-level data from eastern North America (Shuman et al. 2002) and from Mexico (Fritz et al. 2001). I suggest we need to make a more concerted effort to assemble large spatially distributed networks of sites to disentangle localized from regional variability. Dating uncertainties make such comparisons difficult at high temporal resolution, but patterns at centennial to millennial time scales should be apparent in such an approach.

\section{Temporal variability}

The sensitivity of a lake to variation in climate is often evaluated based on a comparison of a core reconstruction spanning the 20th century with modern instrumental climate data to demonstrate that the lake behaves in a predictable way. In down-core interpretations, we assume that these climate-lake relationships are stationary, but in some instances this may not be the case. The physical, chemical, and biological characteristics of lakes can be affected by ex- 


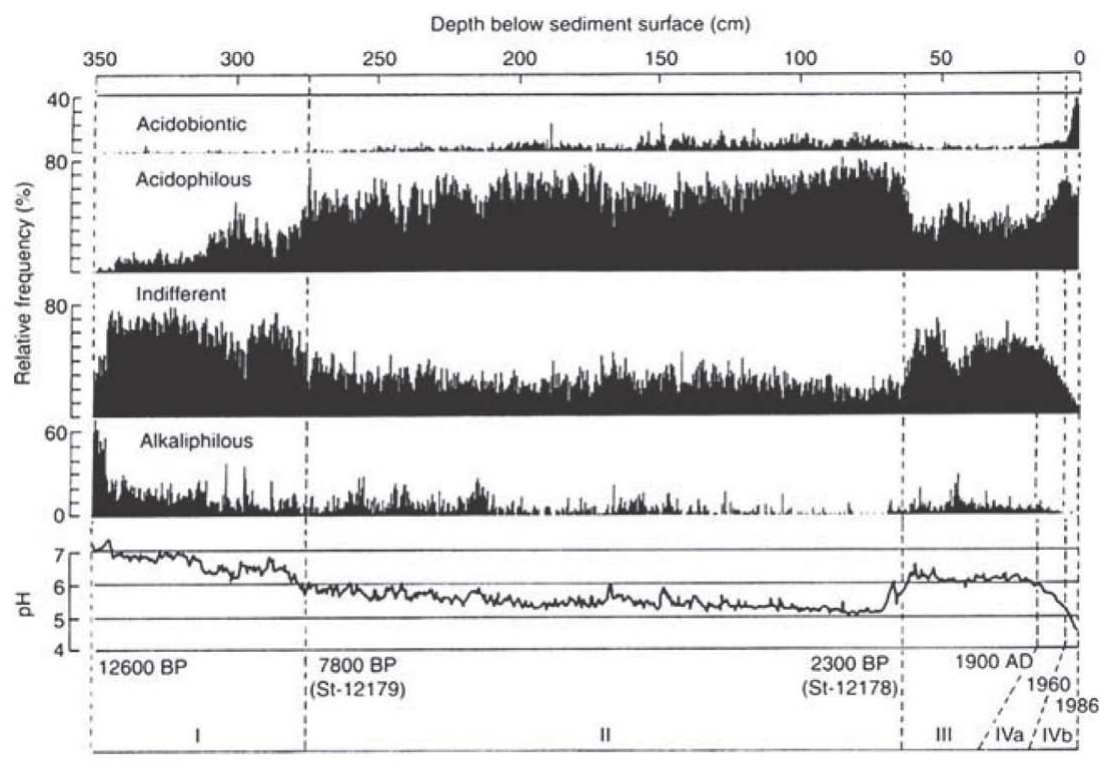

Figure 7 Diatom-based $\mathrm{pH}$ reconstruction spanning the late-glacial and Holocene period for a lake in Sweden. Note that the large and rapid $\mathrm{pH}$ decline in the 20th century is unprecedented relative to the longer record. From Renberg (1990), reproduced by permission of The Royal Society of London ternal drivers, such as climate and climate-induced changes in vegetation and soils; internal processes related to food web structure; and autigenic processes, such as lake infilling, that are part of an evolutionary sequence (Binford and Deevey 1983; Engstrom et al. 2000). Because of these multiple influences, the way in which a lake responds to climate variability may change through time, and the potential for these changes in state need to be considered explicitly in interpreting temporal trends and their causes. One of the most elegant examples of how ecosystem state alters limnological response is a multi-proxy reconstruction of temperature trends in a Swedish lake (Bigler et al. 2002). Most proxies show a trend of increasing temperature from the late-glacial period to the early Holocene (Figure 6), whereas inferences from diatoms do not. In this period of early landscape evolution, changes in lake $\mathrm{pH}$ driven by early soil development were the dominant influence on diatoms. Later, when soil chemistry stabilized, climate became a more prominent influence on diatom species composition, and the diatom-inferred temperature trends mirror those of other proxies.

An increasing number of paleolimnological studies are documenting 20th-century changes in lake ecosystems that are unprecedented relative to recent centuries or occasionally millennia (Smol et al. 2005). The common interpretation is that these changes are a product of human activities via a series of direct or indirect linkages. While these recent changes may be unusual in the context of the recent past, they may not be unique. A pioneering study during the debate on the role of atmospheric deposition in lake acidification (Renberg 1990) recognized the importance of examining recent $\mathrm{pH}$ changes, documented by high-resolution paleolimnological studies, within the context of a very long-temporal framework (Figure 7). Renberg recognized that the relatively coarse temporal resolution of most Holocene paleolimnological studies might have "missed" rapid and short-lived $\mathrm{pH}$ changes. Therefore, evaluating whether or not 20th-century $\mathrm{pH}$ change was unprecedented depended on high-resolution analyses that extended for multiple millennia, not just several centuries. This insightful perspective suggests that it is prudent to consider recent change within the context of other intervals of the late-glacial or Holocene, when mean environmental state was quite different from that of today - both to evaluate whether recent change is unique, as well as to provide some clues as to the mechanisms involved in 20th-century environmental change. In the context of current environmental issues, two groups of diatoms, Cyclotella species and Asterionella formosa, have increased in recent decades in many alpine and Arctic lakes, potentially reflecting changes in nutrient loading (e.g. nitrogen, silica) from the atmosphere or watershed or changes in thermal structure driven by temperature change (Saros et al. 2003; Smol et al. 2005; Wolfe et al. 2001). Although these species have been 


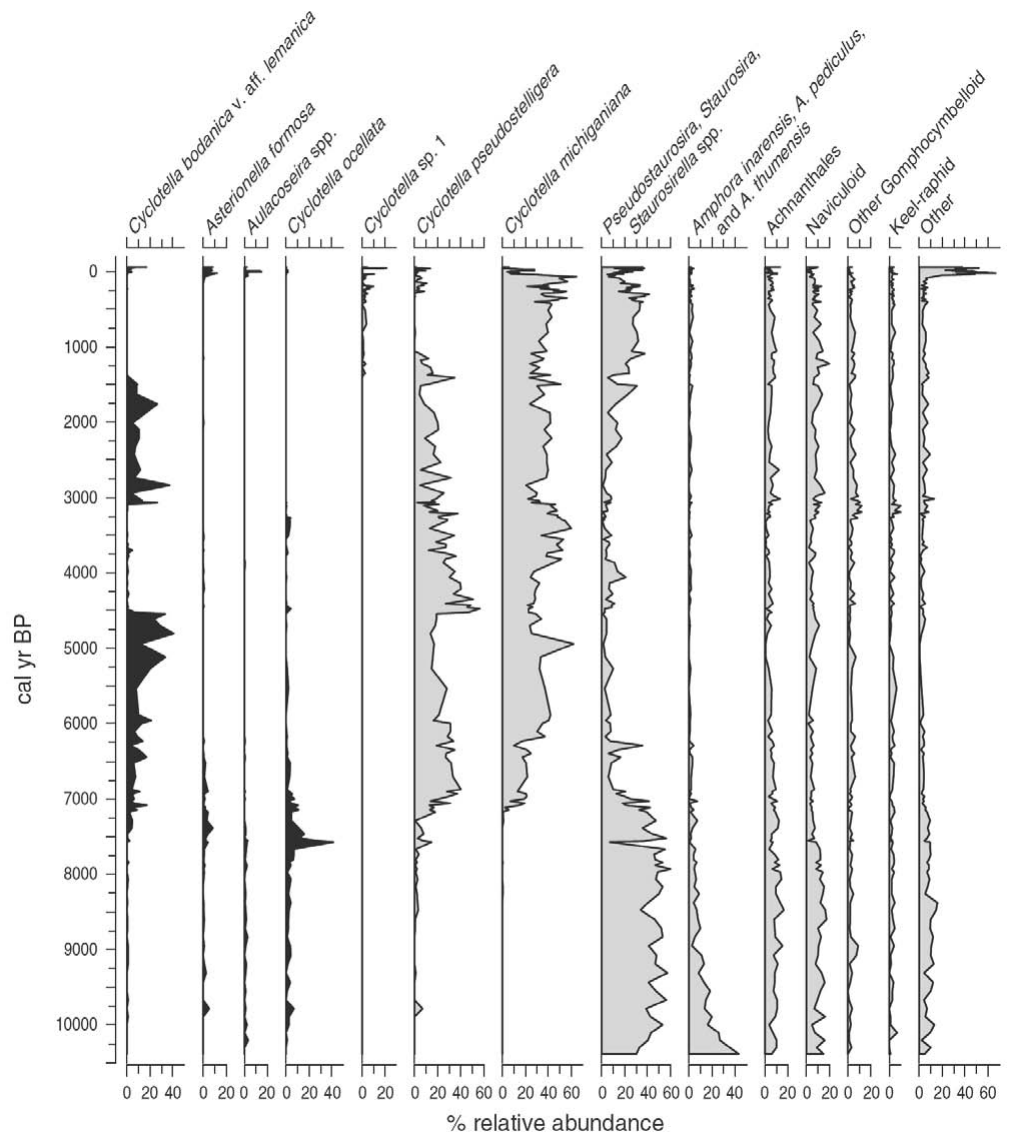

Figure 8 A diatom stratigraphy for an alpine lake in British Columbia. The four species colored black are taxa that are absent for more than a millennia prior to the 20th century and subsequently appear and increase in abundance in the 20th century. The category "other" represents the sum of all taxa not graphed in the figure. Modified from Westover (2006) rare or absent for centuries prior to the 20th century, they may have been common earlier in the record, as is apparent in an alpine lake in British Columbia (Westover 2006; Figure 8). The earlier occurrence of these species in the lake ecosystem does not negate the possibility that 20th-century change may result from human activities or the conclusion that recent conditions are unusual and change was rapid. But the application of high-resolution analyses to longer intervals of time may provide us with analogs for recent assemblages and provide some insights into their proximate drivers. Coupling long-core studies with laboratory or field experiments (Saros et al. 2005) can generate an even more robust insight into the environmental controls of community or ecosystem change.

One of the ultimate goals of paleoclimatic research is to understand the dynamics of the climate system at long time scales, which involves relating climate variation inferred from proxy records to large-scale drivers, such as solar (Hodell et al. 2001) or sea-surface temperature (Stone and Fritz 2006) variability. At high temporal resolution (decadal to multi-decadal), these comparisons are difficult, because of dating uncertainties. One can still, however, assess whether there are common periodicities among records and correlate these periodicities with forcing functions. Yet, interpretation of periodic patterns in proxy records can be challenging, because different components of an ecosystem respond to different aspects of climate variability; for example, some species may respond to spring conditions and others to summer. In addition, as discussed above, different lakes may have different response times to climate variation based on their hydrologic and geomorphic setting. These differential patterns of response can make it difficult to recognize which signals are regionally representative and how they are related to forcing. High-resolution ( 5 year sample spacing) diatom records from a pair of lakes just to the west of Lake Titicaca in Peru (Ekdahl et al. 2007) demonstrate this issue. The two sites show 

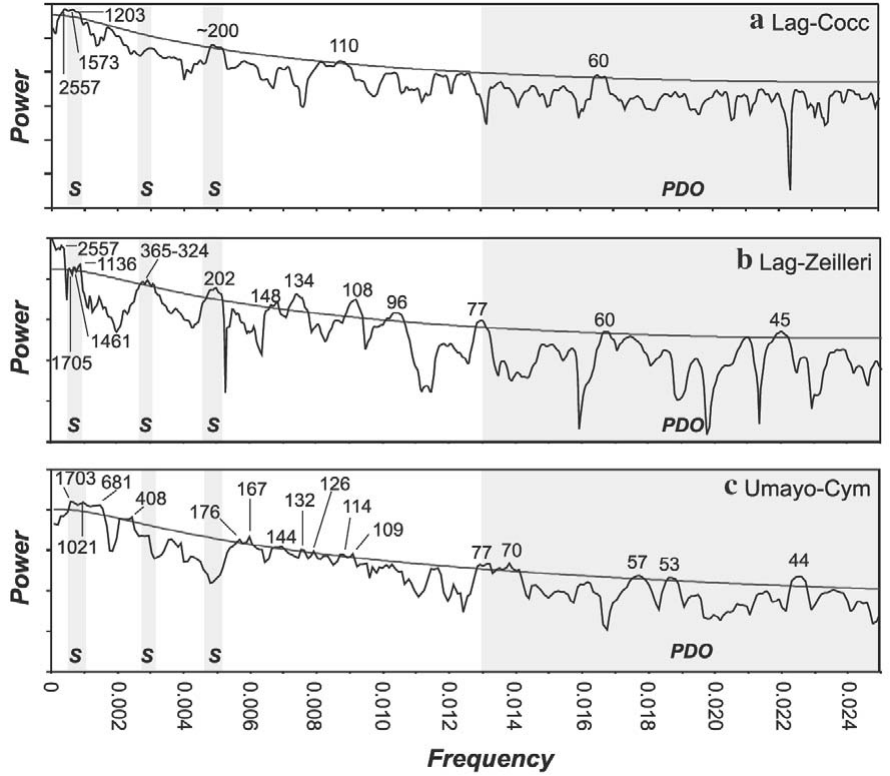

Figure 9 Spectral analysis of the abundance of the diatom species Cocconeis placentula (Cocc) and Fragilaria zeilleri (Zeilleri) in Lago Lagunillas (Lag) and Cymbella cistula plus C. cymbiformis (Cym) in Lago Umayo in Peru. Spectral frequencies characteristic of the Pacific Decadal Oscillation (PDO) and solar variability (s) are shaded gray. The line represents significance at $99 \%$; the ages associated with peaks above this line are indicated. Modified from Ekdahl et al. (2007) very similar trends, including a directional freshening beginning about 5,500 year BP that intensifies after 4,000 year BP. Superimposed upon the directional change is cyclic variation that is apparent in various species. Time series analysis of species data (Figure 9) shows that a 206-year cycle, characteristic of solar variability, is strongly manifested (>99\%) in one of the lakes, but it is not at all strong in the other system. This differential behavior is also true of other frequencies of variation. Similarly, two different benthic species within one lake have some common periodicities of variation, but other periods are strong in one taxon and not the other. A similar degree of variability among regional lakes and among proxies within an individual lake is also apparent in sites in central North America (Brown et al. 2005). In most cases, the causes of the within system and between system differences is unclear. To what extent do these decadal to millennial scale frequencies reflect responses to large-scale forcing versus inherent resonance in these systems at these different temporal scales? Is solar forcing of climate truly manifested in this region, but different lakes and different species are differentially responsive to this frequency of variation? I do not know the answer to these questions, but I think we need to be asking them. Spectral analyses of multiple proxies and large arrays of sites is one tool for addressing some of these issues regarding temporal pacing of variation.

\section{Conclusions}

The proliferation of high-resolution paleolimnological data is giving us new insights into the nature of environmental variability in time and space at multiple scales. Along with the expansion in the number of records has come a growing awareness of the complexities of reconstructing climate from lakes. The non-linear responses of proxies and lakes to climate, in some circumstances, dictates caution in generalizing about how the magnitude of limnological change is related to the magnitude of climate variation. Careful calibration and modeling of basin responses can be used to better constrain the nature of the lake response to climate, although these efforts need to be coupled with the recognition that such relationships may be non-stationary and that a relationship derived from contemporary data may not be relevant throughout the lake's history. It can be difficult to generalize with confidence from the behavior of an individual lake to the regional scale, because of the differences in response times of proxies and basins to climate variability. This is particularly true of lakes where groundwater is a significant portion of the water budget. The issue of spatial scaling is less of a problem for large lakes, which commonly integrate the hydrologic budget of a large area, and, in many cases, are highly responsive to short-term climate variation. One approach for generating region- 
ally robust climate interpretations of multi-decadal to millennial scale variation is to generate reconstructions for a large number of sites, so that one can distinguish localized versus broad-scale patterns. Relating high-frequency (decadal) limnological variation among multiple sites also can be difficult, because of differences in the response rates of individual proxies and lakes and because of inherent errors in dating lake sediments, but common patterns at longer time scales can emerge from regional comparisons. Clearly, paleolimnological analyses are time consuming, but coordinated efforts to generate large data sets and synthesize available data are one of the best means to more fully understand both climate-lake linkages and to continue to advance our knowledge of patterns of climate variation at significant spatial and temporal scales.

\section{Acknowledgments}

I thank John Smol and Bill Last for encouraging me to submit this manuscript and Frank Aebly, Erik Ekdahl, Jeffery Stone, and Karlyn Westover for assistance with figures. A Bullard Fellowship at Harvard Forest (Harvard University) and NSF Grant EAR-0602154 provided partial support during the writing of this paper.

\section{References}

Aebly F, Fritz SC (2007) Paleohydrology of Kangerlussuaq (Sondre Stromfjord), west Greenland during the last $\sim 8000$ years. Holocene (accepted)

Almendinger JE (1993) A groundwater model to explain past lake levels at Parkers Prairie, Minnesota, USA. Holocene 3:105-115

Bigler C, Larocque I, Peglar SM, Birks HJB, Hall RI (2002) Quantitative multiproxy assessment of longterm patterns of Holocene environmental change from a small lake near Abisko, northern Sweden. Holocene 12:481-496

Binford MW, Deevey ES (1983) Paleolimnology: an historical perspective on lacustrine ecosystems. Ann Rev Ecol Syst 14:255-286

Brown KJ, Clark JS, Grimm EC, Donovan JJ, Mueller PG, Hansen B, Stefanova I (2005) Fire cycles in North American interior grasslands and their relation to prairie drought. Proc Nat Acad Sci 102:8865-8870

Cohen AS (2003) Paleolimnology: the history and evolution of lake systems. Oxford University Press, New York

Dean WE (1999) The carbon cycle and biogeochemical dynamics in lake sediments. J Paleolimnol 21:375-393
Digerfeldt G, Almendinger JE, Bjorck S (1993) Reconstruction of past lake levels and their relation to groundwater hydrology in the Parkers Prairie sandplain, west-central Minnesota. Palaeogeogr Palaeoclimatol Palaeoecol 94:99-118

Donovan JJ, Smith AJ, Panek VA, Engstrom DR, Ito E (2002) Climate-driven hydrologic transients in lake sediment records: calibration of groundwater conditions using 20th century drought. Quat Sci Rev 21:605-624

Ekdahl E, Fritz SC, Baker PA, Rigsby CA, Coley K (2007) Holocene multi-decadal to millennial-scale hydrologic variability on the South American Altiplano. Holocene (accepted)

Engstrom DR, Fritz SC, Almendinger JE, Juggins S (2000) Chemical and biological trends during lake evolution in recently deglaciated terrain. Nature 408:161-166

Eugster HP, Hardie LA (1978) Saline lakes. In: Lerman A (ed) Lakes, chemistry geology physics. Springer-Verlag, New York, pp 237-293

Fritz SC, Ito E, Yu Z, Laird KR, Engstrom DR (2000) Hydrologic variation in the northern Great Plains during the last two millennia. Quat Res 53:175-184

Fritz SC, Metcalfe SE, Dean W (2001) Holocene climate patterns in the Americas inferred from paleolimnological records. In: Markgraf V (ed) Interhemispheric climate linkages. Academic Press, New York, pp 241-263

Gorham E, Dean WE, Sanger JE (1983) The chemical composition of lakes in the north-central United States. Limnol Oceanogr 28:287-301

Hodell DA, Brenner M, Curtis JH, Guilderson T (2001) Solar forcing of drought frequency in the Maya lowlands. Science 292:1367-1370

Laird KR, Fritz SC, Maasch KA, Cumming BF (1996) Greater drought intensity and frequency before $\mathrm{AD}$ 1200 in the Northern Great Plains, USA. Nature 384:552-555

McGowan S, Ryves DB, Anderson NJ (2003) Holocene records of effective precipitation in West Greenland. Holocene 13:239-250

Reed JM, Roberts N, Leng MJ (1999) An evaluation of the diatom response to Late Quaternary environmental change in two lakes in the Konya Basin, Turkey, by comparison with stable isotope data. Quat Sci Rev 18:631-646

Renberg I (1990) A 12,600 year perspective on the acidification of Lilla Oresjon, southwest Sweden. Phil Trans Roy Soc Lond B 327:357-361

Russell JM, Johnson TC (2007) Little Ice Age drought in equatorial Africa: ITCZ migrations and ENSO variability. Geology 35:21-24 
Saros JE, Interlandi SJ, Wolfe AP, Engstrom DR (2003) Recent changes in the diatom community structure of lakes in the Beartooth Mountain Range (USA). Arctic Ant Alpine Res 35:18-23

Saros JE, Michel TJ, Interlandi SJ, Wolfe AP (2005) Resource requirements of Asterionella formosa and Fragilaria crotonensis in oligotropic alpine lakes: implications for recent phytoplankton community reoroganizations. Can J Fish Aq Sci 62:1681-1689

Shuman B, Bartlein P, Logar N, Newby P, Webb TW (2002) Parallel climate and vegetation responses to the early Holocene collapse of the Laurentide Ice Sheet. Quat Sci Rev 21:1793-1805

Smith AJ, Donovan JJ, Ito E, Engstrom DR, Panek VA (2002) Climate-driven hydrologic transients in lake sediment records: multiproxy record of mid-Holocene drought. Quat Sci Rev 21:625-646

Smol JP, Wolfe AP, John H, Birks B, Douglas MSV, Jones VJ, Korhola A, Pienitz R, Ruhland K, Sorvari S, Antoniades D, Brooks SJ, Fallu M, Hughes M, Keatley BE, Laing TE, Michelutti N, Nazarova L, Nyman M, Paterson AM, Perren B, Quinlan R, Rautio M, Saulnier-Talbot E, Siitonen S, Solovieva N, Weckstrom J (2005) Climate-driven regime shifts in the biological communities of Arctic lakes. Proc Nat Acad Sci 102:4397-4402

Stevens LR, Stone JR, Campbell J, Fritz SC (2006) A 2200-yr record of hydrologic variability from Foy Lake, Montana, USA, inferred from diatom and geochemical data. Quat Res 65:264-274
Stone JR, Fritz SC (2004) Three-dimensional modeling of lacustrine diatom habitat areas: improving paleolimnological interpretation of planktic:benthic ratios. Limnol Oceanogr 49:1540-1548

Stone JR, Fritz SC (2006) Multidecadal drought and Holocene climate instability in the Rocky Mountains. Geology 34:409-412

Telford RJ, Lamb HF, Mohammed MU (1999) Diatom-derived palaeoconductivity estimates for Lake Awassa, Ethiopia: evidence for pulsed inflows of saline groundwater? J Paleolimnol 21:409-421

Verschuren D, Laird KR, Cumming BF (2000) Rainfall and drought in equatorial east Africa during the past 1,100 years. Nature 403:410-414

Westover KS (2006) Diatom-inferred records of paleolimnlogical and Holocene paleoclimate variability from the Altai Mountains (Siberia) and Columbia Mountains (British Columbia). Ph. D. Thesis, Department of Geosciences, University of Nebraska, Lincoln

Wolfe AP, Baron JS, Cornett RJ (2001) Anthropogenic nitrogen deposition induces rapid ecological changes in alpine lakes of the Colorado Front Range (USA). J Paleolimnol 25:1-7

Zlotnik VA, Burbach M, Swinehart J, Bennett D, Fritz SC, Loope DB, Olaguera F (2007) A case study of direct push methods for aquifer characterization in dune-lake environments of the Nebraska Sand Hills. Environ Eng Geol 13, in press 